\title{
THE RELATIONSHIP OF DISTRIBUTIVE JUSTICE AND PROCEDURAL JUSTICE ON ORGANIZATIONAL COMMITMENT: AN EMPIRICAL TESTING
}

\author{
Binod Ghimire"
}

\begin{abstract}
This paper investigates the relationship between organizational justice and organizational commitment among the employees of different organizations from Kathmandu Valley. This research study analyzes the impact of organizational justice as encompassed by two components, namely distributive justice and procedural justice on employee's commitment. This study is descriptive and analytical. The sample consists of managerial and non-managerial employees who have volunteered to participate in the study. This study reveals a positive and significant relationship showing that the foundation of an employee's commitment is within the application of both distributive and procedural justice, with procedural justice having stronger effect. The findings in this study would offer insight to the managers and business organization in Nepal to formulate strategies that involve in work factors such as distributive and procedural justice for the improvement of the human resource development.
\end{abstract}

Key words: Distributive justice, procedural justice, commitment.

INTRODUCTION AND OBJECTIVE

Organizational commitment is widely described in the management and organizational behavior literature as a key factor for organizational effectiveness. Organizational commitment leads to positive outcomes such as increased effectiveness, performance, productivity, and decreased turnover and absenteeism at the individual and organizational levels. Organizational Justice is one of the antecedents for the development of organizational commitment. Organizational Justice is defined as the perception of employees about the fair treatment in the organizations. It is important issue in the field of human resource management, industrial organizational psychology and organizational behaviour. The concept of organizational justice has developed gradually since Adams (1965) introduced the perception of inequity in distributive issues. One such example of organizational justice is equality; the employees perceive that

* Dr. Ghimire is Lecturer in Faculty of Management, Nepal Commerce Campus, New Baneshwor,TU. 


\section{THE RELATIONSHIP OF DISTRIBUTIVE JUSTICE AND PROCEDURAL ...}

managers treat all of them equally and do not discriminate. The people, who are not treated fairly in their organizations, feel irritated resulting in getting disappointed. Consequently, they would not be loyal. Moreover, such employees do not serve their organization for a longer period of time. Whenever they find the better opportunities, they simply quit the organization.

Most of the researchers divide organizational justice into two categories, namely distributive justice and procedural justice. The reaction of employees at the workplace in response to the management behavior and motivation of employees cannot be understood without distinguishing between two types of justice (Folger \& Konovsky, 1989; Greenberg, 1990). Distributive justice can be defined as treatment on equal basis of employees in terms of salary, working hours, promotion, and other rewards (Adams, 1965). In contrast, if the managers do not design, pay and promote the policy according to the employees' performance, skills, expertise and education, employees would be dissatisfied and would not be committed to the organizations. Procedural justice focuses on the fair dealing of the managers' decision making. Employees are interested in knowing which decision have been made and how they have been made (Cropanzano \& Floger, 1991). Sometimes managers and business owners are required to make tough decisions, and these decisions do not always result in favorable outcomes for every employee. Both research and practical experience have shown us that employees' perceptions of decisions can have dramatic outcomes for the organization.

When an employee believes that he has been treated unjustly, this can lead to a number of negative outcomes for the organization including lower performance, higher turnover intentions, and higher deviant behaviors at work. When an employee believes that she has been treated fairly, this can result in to positive work outcomes such as higher job satisfaction, commitment to the organization, and higher performance. Based on the review of previous study, the study has found that there is considerable research gap concerning the effect of distributive and procedural justice on employee commitment and their long term stay in the organization. The above discussions provide a strong background of the problem to study about impact of organizational justice on employee's commitment in Nepalese organization. This study deals with the following research issues:

- Is the perceived distributive justice significantly related to organizational commitment among employees of Nepalese organizations?

- Is the perceived procedural justice justice significantly related to organizational commitment among employees of Nepalese organizations? 


\section{METHODOLOGY}

Research design, data collection procedure and sampling technique are discussed under this sub-title as follows:

\section{- Research design}

The research design adopted in this study consists of descriptive and correlational. The descriptive research design is a fact finding operation searching for adequate information. It is generally conducted to assess the opinion, behaviors or the characteristic of a given population. It is selected for the study for conceptualization, problem identification, conclusion and suggestion for the study. Analytical approach is followed for the presentation and analysis of data.

\section{- Samples and data collection procedure}

The sample was selected by using convenience sampling where the data collection was done from the employees of above mentioned organizations who were conveniently available to provide it. Most of the respondents were employees working in Kathmandu Valley area as these organizations represent most of the organization in Nepal. Different organizations were selected for this research, located within Valley. Specially, three natures of organizations were selected. They were banking and finance, professional services and educational institutions. Analyzing the relationship between employee perceptions for procedural justice and their intentions to stay with the organization was the main purpose of this study. Also demographic variables such as gender, age, working experience, salary, marital status and educational level were included in the analysis to measure their influences on employee intentions to stay. After having a written permission from the firm's administration, questionnaire was distributed to 120 employees. Each questionnaire was accompanied by a letter explaining the purpose of the research, the voluntary nature of participation, and the confidentiality of the data. And a total of 102 completed questionnaires were returned ( $85 \%$ response rate) from 120 employees. The responses given by the employees were anonymous and confidential. All analysis described below is based on the data and infirmation given by 102 respondents.

\section{- Measures and statistical tools}

Mean, standard deviation, analysis of variance were used as statistical tools. Further, correlation analysis is used to show the relationship among the variables under this study. For the statistical instrument, the 


\section{THE RELATIONSHIP OF DISTRIBUTIVE JUSTICE AND PROCEDURAL ...}

predictor variable of organizational justice (OJ) was measured using 14 items scale. The responses were measured on a five-point likert-scale. The justice scale consists of two dimensions measuring perceptions of distributive justice (DJ) with 6 items and procedural justice (PJ) with 4 items and employee commitment's variable was measured through 4 items. Responses to all items were made on a 5-point Likert scale ranging from (1) Strongly Disagree to (5) Strongly Agree. In addition, respondents' demographic profiles such as age, gender, marital status, educational level, job position, tenure and experience were also asked using nominal scale. In statistical analyses, SPSS version 13.0 was used. Cronbach's alpha test was used for the internal consistency; Spearman correlation coefficient to calculate the correlation between the variables were used in the study. And regression analysis was used because it provided estimates of net effects and explanatory power. The adjusted explained variance (the adjusted $\mathrm{R}$ square) was used in this research to measure explanatory power.

\section{RESULT AND DISCUSSION}

The result and discussion are presented as follows.

Table 1: Number of Respondents

\begin{tabular}{|l|l|l|l|l|}
\hline Sample & Educational & Financial & Professional & Total \\
\hline No of Respondents & Institution & Institution & Institution & \\
\hline No. of Sample from & 17 & 15 & 11 & 43 \\
\hline No of Respondents & 45 & 29 & 28 & 102 \\
\hline $\begin{array}{l}\text { No of questions } \\
\text { distributed }\end{array}$ & 50 & 35 & 35 & 120 \\
\hline No of responses received & 45 & 29 & 28 & 102 \\
\hline$\%$ of responses & $90 \%$ & $82.8 \%$ & $80 \%$ & $85 \%$ \\
\hline
\end{tabular}

Source: Field survey, 2017.

The sample profiles were analyzed. The sample comprised 63.7 percentage $(n=65)$ of male employees compared to 36.3 percentage $(n=37)$ of female employees. Single and Married status were taken into consideration. There 70.5 percentage $(n=72)$ of employees were married where as 29.5 percentage $(n=30)$ of them were single. The age range below 30 was 36.3 percentage $(n=37)$, between 30 to 40 age was 35.2 Percentage $(n=36)$, between 41 to 50 years was 26.5 percentage $(n=27)$, and above 51 years was 2 percentage $(n=2)$. It was found that 16.7 percentage $(n=17)$ of employees had obtained intermediate qualification, 28.4 percentage (n $=29)$ had Bachelor's degree, 56 percentage $(n=56)$ had a master's degree. There were altogether three nature of organization involving 49 percentage 
$(n=50)$ from educational institution, 28.5 Percentage $(n=29)$ from financial institution, and 22.5 percentage $(n=23)$ from professional organization.

\section{Reliability test}

The cronbach's alpha was used to assess the reliability of all constructs, procedural justice, distributive justice, and organizational commitment (Table 2).

Table 2: Reliability Test of Constructs

\begin{tabular}{|l|l|l|}
\hline Constructs & Cronbach's Alpha & No. of Items \\
\hline Procedural Justice & 0.769 & 4 \\
\hline Distributive Justice & 0.870 & 6 \\
\hline Employee Commitment & 0.773 & 4 \\
\hline
\end{tabular}

Source: Field survey, 2017.

From this analysis, all the constructs were higher than significance level of 0.7. Therefore, it could be concluded that all the constructs used for this study were highly reliable. There was no need to drop any of the items from all constructs since the original cronbach's alpha obtained for every construct was rather high i.e. procedural justice recorded 0.769 , distributive justice recorded 0.870 and employee commitment recorded 0.773 .

\section{Relationship of distributive justice and commitment}

The correlation analysis was used to find the relationship of distributive justice and commitment. By the use of SPSS, Pearson correlation was run and result were presented in (Table 3 ).

Table 3: Relationship of Distributive Justice on Commitment

\begin{tabular}{|l|l|l|}
\hline Items & Procedural Justice & Commitment \\
\hline Distributive Justice & 1 & $0.678\left(^{*}\right)$ \\
\hline Org.Commitment & $0.678(*)$ & 1 \\
\hline
\end{tabular}

** Correlation is significant at the 0.01 level (2-tailed).

Source: Field survey, 2017.

Table 3 shows the Pearson Correlation between distributive justice and organizational commitment. The value of Pearson Correlation equals to 0.678 , which had indicated a fair correlation between distributive justice and organizational commitment (Saunders, Lewis, \& Thornhill, 2006). Result also indicates a positive relationship between distributive justice and organizational commitment. Since the p-value was less than 0.05 , 
126 THE RELATIONSHIP OF DISTRIBUTIVE JUSTICE AND PROCEDURAL ...

hence there was significant relationship between distributive justice and organizational commitment with 95 percent confidence level (Table 3).

\section{Relationship of procedural justice and commitment}

The correlation analysis was used to find the relationship of procedural justice and commitment. By the use of SPSS, Pearson correlation was run and result were presented in (Table 4).

Table 4: Relationship of Procedural Justice on Commitment

\begin{tabular}{|l|l|l|}
\hline Items & Procedural Justice & Commitment \\
\hline Procedural Justice & 1 & $0.669^{* *}$ \\
\hline Org.Commitment & $0.669^{*}$ & 1 \\
\hline
\end{tabular}

** Correlation is significant at the 0.01 level (2-tailed).

Source: Field survey, 2017.

The value of Pearson Correlation equal 0.669, which had indicated a fair correlation between procedural justice and organizational commitment. Result also had indicated a positive relationship between procedural justice and organizational commitment. Since the p-value was less than 0.05 , hence there was significant relationship between distributive justice and organizational commitment with 95 percent confidence level (Table 4).

\section{Regression analysis of organizational justice on commitment}

The regression analysis was used to find the impact of procedural and distributive justice on employee commitment. By the use of SPSS, multiple linear regressions were run and result were presented in (Table $5)$.

Table 5: Regression Analysis

\begin{tabular}{|c|c|c|c|c|}
\hline \multirow[b]{2}{*}{ Model } & \multicolumn{2}{|c|}{ Unstandardized Coefficients } & \multirow[b]{2}{*}{ t-statistics } & \multirow[b]{2}{*}{ P-Value } \\
\hline & B & Std.Error & & \\
\hline Constant & 2.887 & 1.095 & 2.637 & 0.010 \\
\hline Distributive Justice & .274 & .074 & 3.724 & 0.000 \\
\hline Procedural Justice & .402 & .120 & 3.364 & 0.001 \\
\hline
\end{tabular}

Source: Field survey, 2017.

From the results obtained in regression analysis as shown in Table 5, the value of $\mathrm{R}$ square equals 0.515 , which mean 51 percent of variation in organizational commitment was due to variation in distributive 
justice and procedural justice. The p-value was low (less than 5 percentage significance level), therefore accepted null hypothesis, whereby the two independent variables (distributive justice and procedural justice) did significantly explain the variance in organizational commitment. Hence, the model adequately explained the relationship between the organizational commitment, distributive justice and procedural justice (there was a goodness of fit). From the result output, the value of the t-test statistic for 'distributive justice' was 3.724 and p-value is very low (less than 5 percent significance level), hence 'distributive justice' had contributed significantly to the model. Similarly, the value of the t-test statistic for 'procedural justice' was 3.364 and p-value was very low (less than 5 percent significance level), hence 'procedural justice' contributes significantly to the model. The explanation of the two independent variables had been done by using the multiple regression equation:

$$
y=a+\beta_{1} x_{1}+\beta_{2} x_{2}+\beta_{3} x_{3}+\beta_{4} x_{4}+\beta_{n} x_{n}
$$

Based on the beta coefficient from the Table 5, the regression weight for 'distributive justice' was 0.274 and 'procedural justice' was 0.402 . Hence, the multiple regression equation (fitted model) was as follows:

Organizational Commitment $=2.887+0.274$ (distributive justice) +0.402 (procedural justice)

Based on the equation above, the relative predictive importance of the independent variables was established by comparing these beta weights, hence it could be concluded that among the two independent variables, procedural justice was more influential than distributive justice in predicting employee's organizational commitment.

\section{CONCLUSION}

The most outstanding finding in this study indicates that there is a significant relationship between employees' perceptions for procedural justice and their commitment to stay with in organization. In other words, employees' perceptions for procedural justice have an influence on their intentions to stay with or leave from an organization. The study results confirm the empirical investigations of many researches such as, Kim and Mauborgne, 1991) which state that when people feel the processes of an organization are fair, they display a high level of voluntary cooperation based on their attitudes of trust and commitment. Conversely, when people feel that the processes are unfair, they may refuse to cooperate and search 


\section{THE RELATIONSHIP OF DISTRIBUTIVE JUSTICE AND PROCEDURAL ...}

for an opportunity, or alternative to leave. Thus, the study results confirm that procedural justice is a key, or a tool for managers to keep employees in an organization, as well as to increase their satisfaction and productivity.

The findings in this study would help managers and business organization in Nepal to formulate strategies that involve in the work factors such as distributive and procedural justice to improve the management of human resource development. These strategies would help in influencing positive behaviors among employees, and hence achieve effectiveness and high productivity in the organization. Therefore, it is worth the effort for the organization to train and educate their managers on the impact of perceptions of organizational justice on the motivation and commitment of their employees.

\section{WORKS CITED}

Adams, J. (1965). Inequity in social exchange. In. L. Berkowitz (ed.). Advances experimental Psychology (Vol. 2). New York: Academic Press.

Cropanzano, R., \& Folger, R. (1991). Procedural justice and worker motivation. In. R. M. Steers \& L. W. Porter (Eds.), Motivation and work behavior, (5 ${ }^{\text {th }}$ ed. pp. 131-143). New York: McGraw-Hill.

Folger R, \& Konovsky, M. (1989). Procedural justice and culture: Effects of cultre, gender, and investigator status of procedural preferences. Journal of Personality and Social Psychology, 50(6). pp. 11341140.

Greenberg, J. (1990). Organizational justice: Yesterday, today, tomorrow, Journal of Management, (16), pp. 399-432.

Kim, W.C, \& Mauborgne, R.A. (1991), Procedural justice, attitudes, and top management compliance with multinationals' corporate strategic decisions, Academy of Management Journal, 36 (3): pp. 502526.

Saunders, M., Lewis P. \& Thornhill A., (2006). Research methods for business students. USA: Prentice Hall. 